\title{
The Political and Social
}

The His Tor Y OF MEDICINE IN CONTEXT
Dynamics of Poverty, Poor

Relief and Health Care in

\section{Early-Modern Portugal}

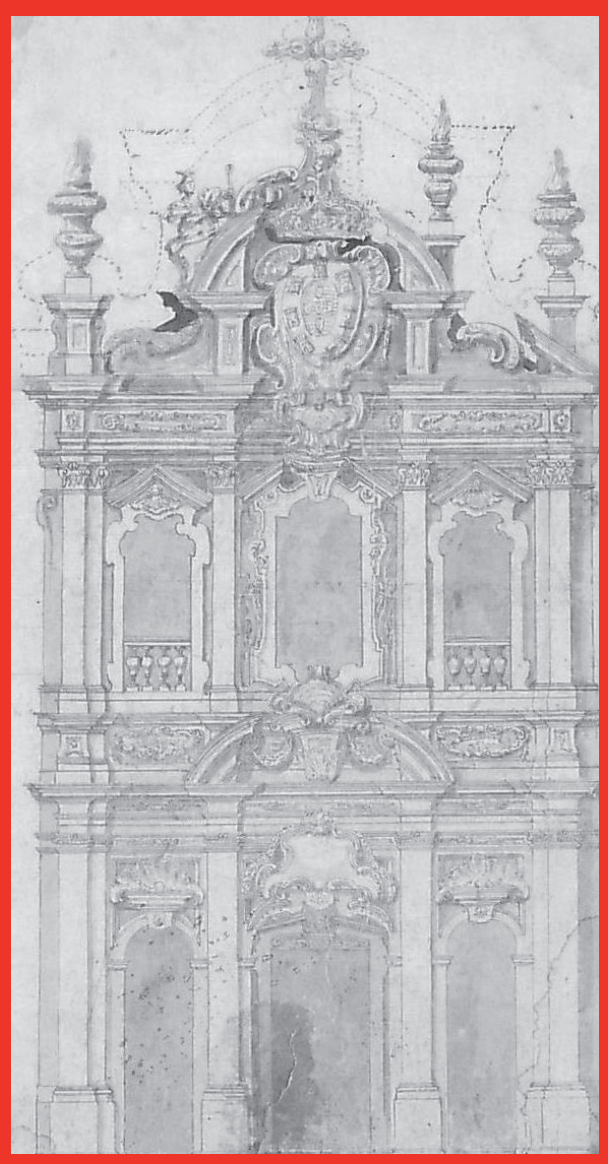

Laurinda Abreu

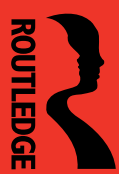




\section{THE POLITICAL AND SOCIAL DYNAMICS OF POVERTY, POOR RELIEF AND HEALTH CARE IN EARLY-MODERN PORTUGAL}

By the end of the fifteenth century most European countries had witnessed a profound reformation of their poor relief and health care policies. As this book demonstrates, Portugal was among them and actively participated in such reforms. Providing the first English language monograph on this topic, Laurinda Abreu examines the Portuguese experience and places it within the broader European context. She shows that, in line with much that was happening throughout the rest of Europe, Portugal had not only set up a systematic reform of the hospitals but had also developed new formal arrangements for charitable and welfare provision that responded to the changing socioeconomic framework, the nature of poverty and the concerns of political powers.

The defining element of the Portuguese experience was the dominant role played by a new lay confraternity, the confraternity of the Misericórdia, created under the auspices of King D. Manuel I in 1498. By the time of the king's death in 1521 there were more than 70 Misericórdias in Portugal and its empire, and by 1640 , more than 300. All of them were run according to a unified set of rules and principles with identical social objectives. Based upon a wealth of primary source documentation, this book reveals how the sixteenth-century Portuguese crown succeeded in implementing a national poor relief and health care structure, with the support of the Papacy and local elites, and funded principally through pious donations. This process strengthened the authority of the royal government at a time which coincided with the emergence of the early modern state. In so doing, the book establishes poor relief and public health alongside military, diplomatic and administrative authorities, as the pillars of centralisation of royal power.

Laurinda Abreu is Professor of History at the University of Évora, Portugal. She is director of the University of Évora's Erasmus Mundus PhD, Phoenix JDP - Dynamics of Health and Welfare. She was the coordinator (2001-09) of the Phoenix TN - European Thematic Network on Health and Social Welfare Policy, and President (2011-13) of the European Association for the History of Medicine and Health. Her recent publications include a co-edited book with S. Sheard (eds), Hospital Life: Theory and Practice from the Medieval to the Modern; and Pina Manique: um reformador no Portugal das Luzes. 


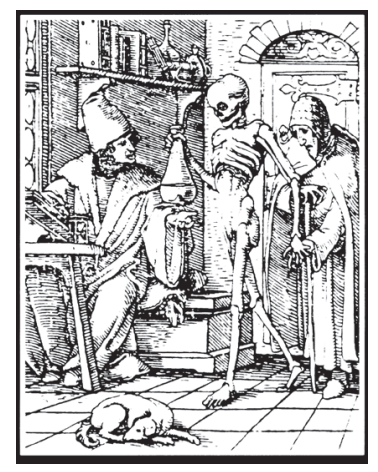

The History of Medicine in Context

Series Editors: Andrew Cunningham and Ole Peter Grell

Department of History and Philosophy of Science

University of Cambridge

Department of History

Open University

Titles in the series include

Uroscopy in Early Modern Europe
Michael Stolberg

The British Pharmacopoeia, 1864 to 2014

Medicines, International Standards and the State

Anthony C. Cartwright

Anatomy and Anatomists in Early Modern Spain

Bjørn Okholm Skaarup

The Fate of Anatomical Collections

Edited by Rina Knoeff and Robert Zwijnenberg

Sudden Death: Medicine and Religion in Eighteenth-Century Rome Maria Pia Donato 


\section{The Political and Social Dynamics of Poverty, Poor Relief and Health Care in Early-Modern Portugal}

LAURINDA ABREU

University of Évora, Portugal 
First published 2016

by Routledge

2 Park Square, Milton Park, Abingdon, Oxon OX14 4RN

and by Routledge

711 Third Avenue, New York, NY 10017

Routledge is an imprint of the Taylor \& Francis Group, an informa business

(c) Laurinda Abreu 2016

The right of Laurinda Abreu to be identified as author of this work has been asserted by her in accordance with sections 77 and 78 of the Copyright, Designs and Patents Act 1988.

All rights reserved. No part of this book may be reprinted or reproduced or utilised in any form or by any electronic, mechanical, or other means, now known or hereafter invented, including photocopying and recording, or in any information storage or retrieval system, without permission in writing from the publishers.

Trademark notice: Product or corporate names may be trademarks or registered trademarks, and are used only for identifi cation and explanation without intent to infringe.

British Library Cataloguing in Publication Data

A catalogue record for this book is available from the British Library

The Library of Congress has cataloged the printed edition as follows:

Names: Abreu, Laurinda.

Title: The political and social dynamics of poverty, poor relief and health care in early-modern Portugal / by Laurinda Abreu.

Description: 2016. | Series: The history

of medicine in context | Includes bibliographical references and index.

Identifiers: LCCN 2015026609 | ISBN 9781472477255 (hardcover : alkaline paper) | ISBN 9781315554525 (ebook) |

Subjects: LCSH: Poor-Services for Portugal-History. | Poor-Medical care-Portugal-History. | Poverty-Social aspects-Portugal-History. |

Poverty-Political aspects-Portugal-History. |

Charities-Portugal-History. | Public welfare-Portugal-History. |

Medical policy-Portugal-History. | Portugal-Social policy. |

Portugal-Politics and government. | Portugal-Social conditions.

Classification: LCC HV4129.A3 A25 2016 | DDC 362.109469/09031-dc23 LC record available at http://lccn.loc.gov/2015026609

ISBN: 9781472477255 (hbk)

ISBN: 9781315554525 (ebk)

Typeset in Garamond Premier Pro 


\section{Contents}

List of Figures and Tables vii

Introduction 1

PART I CHARITY AND POOR RELIEF IN PORTUGAL AT THE DAWN OF THE EARLY MODERN PERIOD: THE ORGANISATION AND CONSOLIDATION OF CROWN AUTHORITY

$1 \quad$ Social and Political Contexts 9

2 'For the Benefit of the Body': Hospital and Health Care Reform 25

3 Epidemic Control 45

4 The Foundation of the Misericórdias 55

$5 \quad$ The Organisation of the Welfare 'System' 89

6 The Funding of Poor Relief 113

PART II INSTITUTIONS AS SOCIAL ACTORS MEDIATING BETWEEN SOCIETY, THE AUTHORITIES AND INDIVIDUALS

$7 \quad$ Poor Relief in an Institutional Context

8 The Movement to Found Confinement Institutions 147

9 The Population of Female Recolhimentos: 'wives, nuns and prostitutes'

10 Hospitals and their Users

11 Prisons and Misericórdias 
Conclusion

Sources

Bibliography

271

Index 


\section{List of Figures and Tables}

\section{Figures}

5.1 Municipalities Required to Finance the Training of Doctors and Apothecaries

5.2 Municipalities Required to Finance the Training of Doctors and Apothecaries; Misericórdias

5.3 Municipalities that Financed Training and Hired Doctors, Apothecaries and Surgeons

10.1 Espírito Santo Hospital, Évora: Hospital Admissions $1628-1753$

10.2 Espírito Santo Hospital, Évora: Monthly Admission Figures

\section{Tables}

8.1 Poor Relief Institutions (c. 1540-1804) 148

10.1 Patterns of Hospitalisation in Espírito Santo Hospital, Évora 


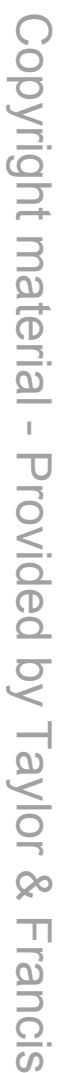




\section{Introduction}

Poor relief in the early modern period is now a well-established field of study. It has attracted a large number of researchers, who have taken a variety of approaches and focused on many different aspects. This book examines how this field developed in early modern Portugal in tandem with the incipient forging of the state. It draws on the work of historians such as Paul Slack, who, particularly since the 1980s, ${ }^{1}$ have emphasised the political nature of the subject. ${ }^{2}$ More specifically, the intention here is to place poor relief and public health alongside war, the army, diplomacy and government on the list of topics that are usually identified as pillars of centralised royal power.

The people were essential to the political authorities, and not only in numerical terms. As a rule, the number of poor people receiving relief was quite small, excluding, of course, the poor who received alms given spontaneously, either in an institutional context or privately, the social impact of which will always be impossible to evaluate. This is because the eligibility criteria for receiving formal poor relief - charity given in an institutional context with some degree of bureaucratic control ${ }^{3}$ - served as a powerful filter, which limited the number of potential users. Not all poor people could satisfy the moral canons, the physical and age requirements that prioritised the old, the very young, the disabled, the sick and their families and those who were temporarily or permanently unable to work, as well as certain circumstances associated with an individual's life history ${ }^{4}$ and the requirement of a fixed abode. ${ }^{5}$ Even if all these conditions were fulfilled, there was no guarantee that a poor person would be accepted for relief in a highly competitive world of scarce resources. In the mid-seventeenth century, only 6 per cent of the population of Antwerp received institutional aid either regularly or sporadically; ${ }^{6}$ the same percentage was found in towns in Catholic

$1 \quad$ See Grell and Cunningham, 1997, pp. 1-17.

2 See Barry and Jones, 1994. This does not mean that the role of the religious values and principles that dominated early modern society should be underestimated. Of the abundant literature on these issues, see in particular Parker, 1998.

3 Hindle, 2004, and Dinges, 2004, pp. 23-50.

4 Woolf, 1986.

5 Even if the variability of this socially constructed concept (poor) is taken into account. See Simmel, 1965, pp. 137-8.

6 Roughly 4,000 of the city's 63,000 inhabitants. See Soly, 1997, p. 98. 
Germany $^{7}$ and in Stockholm, among other European cities. ${ }^{8}$ In Portugal, Évora was not far off this mark, perhaps with 7-8 per cent, if one includes the charity handed out in the hospital - which mainly looked after migrant workers - and the safe-conducts given to help poor people, mostly non-residents, to leave the city. In Lisbon only 1.5 per cent of the population was succoured by the misericórdia (House of Mercy) in the financial year 1715-16, which was probably about average for the number of poor people helped each year. These figures are low in comparison with a number of estimates suggesting that 30-50 per cent of Europe's population in the late Middle Ages and early modern period was living below the poverty line. ${ }^{10}$ At this point, however, we need to broaden our field of view to include the various bodies involved in helping the poor. This examination should not be confined to those organisations that had the means to operate as instruments of social normalisation and thereby serve the purposes of the authorities and dominant groups, but should embrace society in general. Poor relief was a factor for social cohesion and was seen as such by the authorities, which were often open to interactions and negotiations that were of undeniable socio-political significance. ${ }^{11}$ Furthermore, for many people poor relief also provided an occupation and allowed access to benefits that would otherwise be denied to them. The case of foster-mothers for foundling infants is already relatively well known. An occupation discussed below is that of alms collectors, a highly sought-after activity practised by a large number of men who, by appealing for donations for the poor, lifted themselves out of manual labour and paying taxes.

The operational concepts of collective action and actors with interests, as formulated by Dorothy Porter ${ }^{12}$ and Marco Van Leeuwen, ${ }^{13}$ are significant in this context. One of their main advantages is that they are integrative, embracing all the actors involved in poor relief: those who provided the funds, those who organised their distribution (not necessarily the same groups), and the beneficiaries.

7 Between 6 and 10 per cent in some cases. See Roeck, 1999, pp. 283-4.

8 Kouri, 1997, p. 182; Slack, 1988; Jütte, 1996a, pp. 53-4. A little later, between 1755 and 1794, it was 7-13 per cent in several towns in the Netherlands. See Lis and Soly, 1985, pp. 194-5.

9 João Brandão calculated roughly 1,000-2,000 poor people begging in Lisbon in 1552. João Brandão, 1990, pp. 89-90.

10 The complexity of this issue is discussed by John Henderson and Richard Wall, in their excellent introduction to Poor Women and Children in the European Past, 1994.

11 Munck, unpublished.

12 Dorothy Porter, 1999a, pp. 9-21, and 1999b. On the application of these tools to the Portuguese case, see Abreu, 2010b, pp. 347-71.

13 Van Leeuwen, 1994, pp. 589-613. 